\title{
Reduced Levels of Serotonin 2A Receptors Underlie Resistance of Egr3-Deficient Mice to Locomotor Suppression by Clozapine
}

\author{
Alison A Williams', Wendy M Ingram², Sarah Levine ${ }^{3}$, Jack Resnik ${ }^{4}$, Christy M Kamel ${ }^{4}$, James R Lish ${ }^{4}$, \\ Diana I Elizalde ${ }^{4}$, Scott A Janowski ${ }^{3}$, Joseph Shoker ${ }^{4}$, Alexey Kozlenkov ${ }^{5}$, Javier González-Maeso ${ }^{5,6}$ and \\ Amelia L Gallitano*,4
}

'School of Life Sciences, Arizona State University, Tempe, AZ, USA; '2Department of Molecular and Cell Biology, Life Sciences Addition, University of Califormia, Berkeley, CA, USA; ${ }^{3}$ University of Arizona College of Medicine-Tucson, Tucson, AZ, USA; ${ }^{4}$ Department of Basic Medical Sciences and Psychiatry, University of Arizona College of Medicine - Phoenix, Phoenix, AZ, USA; ${ }^{5}$ Department of Psychiatry, Mount Sinai School of Medicine, New York, NY, USA; ${ }^{6}$ Department of Neurology, Mount Sinai School of Medicine, New York, NY, USA

\begin{abstract}
The immediate-early gene early growth response 3 (Egr3) is associated with schizophrenia and expressed at reduced levels in postmortem patients' brains. We have previously reported that Egr3-deficient $\left(\right.$ Egr $3^{-/-}$) mice display reduced sensitivity to the sedating effects of clozapine compared with wild-type (WT) littermates, paralleling the heightened tolerance of schizophrenia patients to antipsychotic side effects. In this study, we have used a pharmacological dissection approach to identify a neurotransmitter receptor defect in Egr $3^{-/-}$mice that may mediate their resistance to the locomotor suppressive effects of clozapine. We report that this response is specific to secondgeneration antipsychotic agents (SGAs), as first-generation medications suppress the locomotor activity of Egr $3^{-1-}$ and WT mice to a similar degree. Further, in contrast to the leading theory that sedation by clozapine results from anti-histaminergic effects, we show that $\mathrm{HI}$ histamine receptors are not responsible for this effect in C57BL/6 mice. Instead, selective serotonin $2 \mathrm{~A}$ receptor $\left(5 \mathrm{HT} \mathrm{T}_{2 \mathrm{~A}} \mathrm{R}\right)$ antagonists ketanserin and MDL- I 1939 replicate the effect of SGAs, repressing the activity in WT mice at a dosage that fails to suppress the activity of $\mathrm{Egr}^{-1-}$ mice. Radioligand binding revealed nearly $70 \%$ reduction in $5 \mathrm{HT}_{2 \mathrm{~A}} \mathrm{R}$ expression in the prefrontal cortex of Egr3 ${ }^{-1-}$ mice compared with controls. Egr3 ${ }^{-1-}$ mice also exhibit a decreased head-twitch response to $5 \mathrm{HT}_{2 \mathrm{~A}} \mathrm{R}$ agonist I-(2,5-dimethoxy 4-iodophenyl)2-amino propane (DOI). These findings provide a mechanism to explain the reduced sensitivity of Egr $3^{-1-}$ mice to the locomotor suppressive effects of SGAs, and suggest that $5 \mathrm{HT}_{2 \mathrm{~A}} \mathrm{Rs}$ may also contribute to the sedating properties of these medications in humans. Moreover, as the deficit in cortical $5 \mathrm{HT}_{2 \mathrm{~A}} \mathrm{R}$ in $\mathrm{Egr}^{-1-}$ mice aligns with numerous studies reporting decreased $5 \mathrm{HT}_{2 \mathrm{~A}} \mathrm{R}$ levels in the brains of schizophrenia patients, and the gene encoding the $5 \mathrm{HT}_{2 \mathrm{~A}} \mathrm{R}$ is itself a leading schizophrenia candidate gene, these findings suggest a potential mechanism by which putative dysfunction in EGR3 in humans may influence risk for schizophrenia. Neuropsychopharmacology (2012) 37, 2285-2298; doi: I0.1038/npp.20।2.8I; published online I3 June 2012
\end{abstract}

Keywords: 5HT2A receptor; clozapine; Egr3; immediate early gene; locomotor activity; schizophrenia/antipsychotics

\section{INTRODUCTION}

The immediate-early gene early growth response 3 (Egr3) is associated with schizophrenia risk (Kim et al, 2010; Yamada et al, 2007; Zhang R et al, 2012) and expressed at reduced levels in the brains of patients with the mental illness (Mexal et al, 2005; Yamada et al, 2007). Animal studies also support a role for Egr3 in schizophrenia pathogenesis. We have previously reported that Egr3deficient $\left(\mathrm{Egr}^{-1-}\right)$ mice display locomotor hyperactivity, a

*Correspondence: Dr AL Gallitano, Department of Basic Medical Sciences and Psychiatry, University of Arizona College of Medicine-Phoenix, 425 North 5th Street, Phoenix, AZ 85004, USA, Tel: + I 602827 2131,

Fax: + I 6028272130 ,

E-mail: amelia@email.arizona.edu

Received 22 December 2011 ; revised 6 April 2012; accepted 26 April 2012 phenotype associated with schizophrenia (Gainetdinov et al, 2001), which is reversed by treatment with either haloperidol or clozapine (Gallitano-Mendel et al, 2008). However, the response of the mice to these two medications was distinctly different. Whereas the dose of haloperidol that normalized the hyperactivity of $\mathrm{Egr}^{-1-}$ mice did not affect the locomotion of wild-type (WT) control animals, the dosage of clozapine required to normalize the activity of $\mathrm{Egr3}^{-1-}$ mice profoundly suppressed the locomotor activity in their WT littermates (Gallitano-Mendel et al, 2008). This relative resistance to the locomotor suppression effects of clozapine, compared to controls, parallels the heightened tolerance of schizophrenia patients to the side effects of antipsychotics (Cutler, 2001). The cause of this effect in either humans or $\mathrm{Egr}^{-l-}$ mice is not known. Like in humans, identification of the neurobiological cause of abnormal behaviors in gene-deficient mice can be remarkably challenging. 
Indeed, prior histological studies failed to identify differences in levels of neurotransmitter receptors in the brains of $\mathrm{Egr3}^{-1-}$ mice to explain these abnormalities (Tourtellotte and Milbrandt, 1998). This points to a need for methods to identify receptor differences that underlie behavioral and pharmacological abnormalities in genetically altered mice.

Clozapine remains one of the leading antipsychotic medications to date, yet its mechanism of action remains unknown. This is due, in part, to its complex receptor binding profile. Clozapine binds to a wide range of receptors in the brain, including numerous subtypes of dopamine, serotonin, histamine, adrenergic, and muscarinic receptors (reviewed in Meltzer and Huang (2008), Roth et al (2004), and Stahl (2008)). The mechanism underlying the sedating effects of clozapine in humans is also unknown, although it is frequently attributed to antagonism of the histamine H1 receptor (Casey, 1997). We hypothesized that, by systematically testing a range of pharmacological compounds, which bind to subsets of receptors in the clozapine binding profile (ie, a 'pharmacological dissection'), we could identify the receptor subtype responsible for the resistance of $\mathrm{Egr}^{-1-}$ mice to the locomotor activity suppression by clozapine. This should shed light on the mechanism underlying the sedating effects of clozapine in humans. In addition, this method should identify a neurotransmitter receptor defect in $E g r 3^{-1-}$ mice, providing a clue into a neurobiological abnormality of schizophrenia patients, while also revealing the next step of our hypothesized pathway of schizophrenia susceptibility genes (Gallitano-Mendel et al, 2008).

In this study, we show several novel findings resulting from this approach. First, the $\mathrm{H} 1$ histamine receptor is not responsible for the resistance of $\mathrm{Egr}^{-1-}$ mice to locomotor suppression by clozapine. Second, we demonstrate that the locomotor activity response of $\mathrm{Egr}^{-1-}$ mice appears to distinguish second-generation antipsychotics (SGAs, also known as 'atypical antipsychotics') from first-generation antipsychotics (FGAs, also known as 'typical antipsychotic'). Third, we show that selective antagonists for the serotonin $2 \mathrm{~A}$ receptor $\left(5 \mathrm{HT}_{2 \mathrm{~A}} \mathrm{R}\right)$ suppress the locomotor activity of WT, but not $E g r 3^{-I-}$, mice and thus mimic the effect of clozapine. Finally, we find that $\mathrm{Egr}^{-1-}$ mice have a nearly $70 \%$ decrease in $5 \mathrm{HT}_{2 \mathrm{~A}} \mathrm{R}$ binding in the prefrontal cortex (PFC) and display a blunted behavioral head-twitch response to $5 \mathrm{HT}_{2 \mathrm{~A}} \mathrm{R}$ agonist 1-(2,5-dimethoxy 4-iodophenyl)-2-amino propane (DOI). These findings suggest that action at the $5 \mathrm{HT}_{2 \mathrm{~A}} \mathrm{R}$ contributes to the locomotor suppressive effects of clozapine and other SGAs in mice, and may play a role in the sedating effects of these medications in humans. Furthermore, the reduced levels of $5 \mathrm{HT}_{2 \mathrm{~A}} \mathrm{Rs}$ we identified in $\mathrm{Egr}^{-1-}$ mice parallel the results of numerous in vivo and post-mortem studies that report decreased levels of $5 \mathrm{HT}_{2 \mathrm{~A}} \mathrm{Rs}$ in the frontal cortex of schizophrenia patients, including first-break, untreated individuals (Dean and Hayes, 1996; Erritzoe et al, 2008; Garbett et al, 2008; Hurlemann et al, 2008; Lopez-Figueroa et al, 2004; Matsumoto et al, 2005; Ngan et al, 2000; Rasmussen et al, 2010; Serretti et al, 2007). Taken together, these findings suggest a possible mechanism through which human Egr3 may influence susceptibility to schizophrenia.

\section{MATERIALS AND METHODS}

\section{Animals}

Previously generated $\mathrm{Egr}^{-1-}$ mice (Tourtellotte and Milbrandt, 1998) were backcrossed to C57BL/6 mice for more than 20 generations. Animals were housed on a 14/10 h light/ dark schedule with ad libitum access to food and water. A large breeding colony of $\mathrm{Egr}^{+/-} \times \mathrm{Egr}^{+/-}$mice was maintained to produce study animals. Studies were conducted on adult male littermate progeny of these matings.

\section{Behavioral Testing}

Behavioral testing was performed during daytime hours under ambient light conditions. Progeny male $+I+$ and $-I-$ animals were identified as 'matched pairs' at the time of genotyping and added to experimental cohorts at a minimum of 2 months of age. A total of 10 independent cohorts of animals were used throughout the course of all behavioral studies. To accommodate IACUC recommendations for reduction of animal numbers, mice were used in an average of three tests before being euthanized by $\mathrm{CO}_{2}$ asphyxiation. All animals were killed by the age of 12 months, if not before. Between tests, mice underwent a washout period of greater than, or equal to, five drug half-lives, and were rerandomized into treatment groups, to minimize possible confounds from repeated use. Furthermore, testing for each drug was replicated in a second, independent cohort of mice. Locomotor activity effects were robust and replicable, reducing the likelihood of possible confounds secondary to re-use of animals. Specific sample sizes per group, per experiment are included in the figure legends for each study.

\section{Activity Monitoring}

The effect of pharmacological agents on the locomotor activity of WT and $\mathrm{Egr}^{-{ }^{-}-}$mice was measured using the SmartFrame system (Kinder Scientific, Poway, CA) (Table 1). Drug dosages were selected following literature review and subsequent dose-response testing in pilot groups of WT C57BL/6 mice to establish the dosage that suppressed locomotor activity in WT mice (Supplementary Figure S1). The suppressive dosage, vehicle control, and intermediate dosages were then tested in a large cohort of matched $\mathrm{Egr3}^{-I-}$ and WT littermates. All studies were replicated in a second, separate cohort of animals. The second of the replicate studies is presented in the Results section.

Activity was evaluated in transparent $\left(47.6 \times 25.4 \times 20.6 \mathrm{~cm}^{3}\right.$ high) polystyrene enclosures using a computerized photobeam system (MotorMonitor Kinder Scientific). Animals were placed in the enclosures $20 \mathrm{~min}$ after drug administration, and activity was monitored for $1 \mathrm{~h}$. Locomotor activity was calculated using a number of movements (total photobeam breaks) as the dependent variable for total activity. The term 'Reduced' is used for statistically significant decreases in locomotor activity, compared with vehicle-treated animals of the same genotype, which remain $>1000$ movements per $h$. Decreases in locomotor behavior below 1000 movements per $h$ are labeled 'suppressed'. 
Table I Effect of Drugs Targeting Receptors Bound by Clozapine on the Activity of WT and Egr3 ${ }^{-1-}$ Mice

\begin{tabular}{|c|c|c|c|c|}
\hline \multirow{2}{*}{ Drug } & \multirow{2}{*}{$\begin{array}{l}\text { High affinity target } \\
\text { receptors* }\end{array}$} & \multirow{2}{*}{ Dosage (mg/kg) } & \multicolumn{2}{|c|}{ Activity } \\
\hline & & & WT & $\mathrm{Egr3}^{-I-}$ \\
\hline \multicolumn{5}{|l|}{ Antipsychotics } \\
\hline Clozapine & $\begin{array}{l}\text { AIA, HI, AIB; 5-HT2A; MI-2; 5-HT6-7; M3; A2B; } \\
\text { M4; 5-HT2C; A2C; D4; M5 }\end{array}$ & $3.5,5,7$ & Suppressed & Reduced \\
\hline Haloperidol & D2; AIA-B; D3-4; 5-HT2A; DI & $0.03,0.1,0.3$ & Suppressed & Suppressed \\
\hline Olanzapine & $\begin{array}{l}\text { 5-HT2A; HI; 5-HT6; M5; D4; 5-HT2C; MI; A2C; H2; } \\
\text { M3; DI-3; M2; A2B; D5 }\end{array}$ & $1,2,3$ & Suppressed & Reduced \\
\hline Quetiapine & $\mathrm{HI} ; \mathrm{AIA}-\mathrm{B} ; \mathrm{A} 2 \mathrm{C}$ & 10,20 & Suppressed & Reduced \\
\hline Ziprasidone & $\begin{array}{l}\text { 5-HT2A; 5-HTIB; D2; 5-HT7; 5-HTD; AIB; D3; AIA; } \\
\text { 5-HT2B; DI; A2B; 5-HT6; 5-HT2C; 5-HTIA; A2C }\end{array}$ & $2.5,5,7,10$ & Suppressed & Reduced \\
\hline \multicolumn{5}{|l|}{ HI antagonists } \\
\hline Promethazine & $\mathrm{HI}$ & 10,50 & Suppressed & Suppressed \\
\hline Pyrilamine & $\mathrm{HI}$ & 10,50 & No change & N/A \\
\hline \multicolumn{5}{|l|}{ 5-HT2A antagonists } \\
\hline ACP-I03 & $5-\mathrm{HT} 2 \mathrm{~A}$ & 15 & Suppressed & Reduced \\
\hline Ketanserin & 5-HT2A; HI; 5-HT2C & $2.5,5,10$ & Suppressed & Reduced \\
\hline MDL-II939 & 5-HT2A, 5-HTIB & $2.5,5,10$ & Suppressed & Reduced \\
\hline \multicolumn{5}{|c|}{ Additional drugs targeting other receptors } \\
\hline Ifenprodil & NMDA/NR2B selective & 20,40 & No change & N/A \\
\hline Medetomidine & $\alpha 2$ agonist & $0.01,0.1,1$ & Suppressed & Suppressed \\
\hline
\end{tabular}

Dose-response curves for each drug were tested in WT mice. If the agent was found to suppress the locomotor activity in a 60 min test, further tests were performed in matched $\mathrm{Egr}^{-1-}$ and WT mice to determine whether the response differed between the two genotypes. *Reported receptor ligands that bind with $K_{\mathrm{i}}<100 \mathrm{nM}$ according to PDSP website (Roth, 2008). Receptor subtypes are listed in the order of binding affinity, from highest to lowest. See Table 2 for complete binding profiles and $K_{i}$ values. Suppressed: Activity decreased below 1000 movements in I h of monitored locomotor activity. Reduced: Locomotor hyperactivity significantly reduced $(p<0.05)$; compared with vehicle-treated mice of the same genotype, but well above 1000 movements per hour. No change: No significant change in a I h locomotor activity test compared with vehicle-treated controls. N/A: No change detected in dose-response curve with WT mice, thus no subsequent tests with Egr $3^{-1-}$ mice were conducted. References: Bespalov et al (2007), Buckton et al (200 I), Cosi et al (2005), Crawley ( I98I), Dougherty and Aloyo (20 I I), Fox et al (20 I0), Fukushiro et al (2007), Kamei et al (2005), Kehne et al (1996), Kinkead et al (2005), Kyncl (1986), Lynch et al (201 I), MacDonald et al (199I), Moore et al (1992), O'Dell et al (2000), Oduola et al (2004), Philibin et al (2005), Rasmussen and Fink-Jensen (2000), Redrobe and Bourin (1997), Simon et al (2000), Vanderwolf (199I), Vanover et al (2006), Votava et al (2008), Yan et al (2007), Zarnowski et al (1994), and Zhu et al (2004).

Data are depicted as graphs of average total activity in response to drug dosage for each genotype. In addition, the same data are also graphed to show the percentage decrease in activity compared with vehicle-treated controls of the same genotype. For the latter graph, each animal was compared to the average of all vehicle-treated animals of the same genotype to generate individual 'percent change in activity' values. These values were then averaged for all mice in a treatment group (defined by genotype and drug dosage) to produce bar graphs. Error bars in all graphs denote standard error of the mean for each treatment group.

\section{Video Recording}

After completion of testing, a subset of WT and $E g r 3^{-1-}$ mice were video recorded following administration of FGA chlorpromazine $(10 \mathrm{mg} / \mathrm{kg})$, SGA olanzapine $(3 \mathrm{mg} / \mathrm{kg})$, and $5 \mathrm{HT}_{2 \mathrm{~A}} \mathrm{R}$-specific antagonist MDL-11939 (10 mg/kg). Littermate animals were administered either drug or vehicle and allowed to acclimate for $30 \mathrm{~min}$ before the removal of the cage lid for brief recording with a hand-held video camcorder. Gentle shaking of the cage by the investigator was used to stimulate the activity of immobile mice.

\section{Drowsiness, Motor impairment, and Stereotypic Behavior Assessment}

The effect of haloperidol $(3 \mathrm{mg} / \mathrm{kg})$ and clozapine $(7 \mathrm{mg} / \mathrm{kg})$ on drowsiness, motor impairment, and stereotypic behavior was assessed in a cohort of WT and $E g r 3^{-l-}$ mice. Behavior was scored for a period of $2 \mathrm{~min}$ at 30 and $60 \mathrm{~min}$ postdrug administration. Abnormal movements were scored 
according to a behavioral checklist for stereotypy and dyskinesia, adapted from McNamara et al. (2006) and Khan et al. (2004). The categories scored included: grooming episodes, head bobbing, and myoclonic twitches of the abdomen, head/facial, and limb regions. The total number of head bobs, and face, trunk, or limb twitches in the $2 \mathrm{~min}$ period were summed to produce a total stereotypy count. Grooming episodes were rare across all groups, and therefore not included. A second assessment was performed using a sedation and motor impairment rating scale adapted from Aitchison et al. (2000). Scores represent the average of two independent observers blind to both genotype and treatment. A detailed protocol and rating scales are included in Supplementary Materials.

\section{DOI-Induced Head-Twitch Response}

Head-twitch response to DOI $(1 \mathrm{mg} / \mathrm{kg})$ was assessed as described previously (Gonzalez-Maeso et al, 2003). Animals were placed in a transparent polystyrene cage $15 \mathrm{~min}$ following administration of drug or vehicle and video recorded for $30 \mathrm{~min}$ at close range by a camera suspended above the cage. Head twitches were independently scored by two observers blind to genotype and treatment, and scores were averaged for statistical analysis.

\section{Radioligand Binding Assay}

Radioligand binding with $\left[{ }^{3} \mathrm{H}\right]$ ketanserin was used to measure the level of expression of $5-\mathrm{HT}_{2 \mathrm{~A}} \mathrm{R}$ in the PFC of drug-naive $\mathrm{Egr}^{-1-}$ and WT littermate control mice. Animals were killed via $\mathrm{CO}_{2}$ asphyxiation, brains were immediately removed, and the PFC was dissected from a coronal slice spanning from Bregma: 1.95, Interaural: 5.78 and Bregma: 0.00, Interaural: 3.80, using the Coronal C57BL/6J Atlas from the Mouse Brain Library (Rosen et al, 2000). Collected tissue was snap-frozen on dry ice and stored at $-80^{\circ} \mathrm{C}$ until binding studies were performed. $\left[{ }^{3} \mathrm{H}\right]$ Ketanserin (DuPont-NEN, Boston, MA) binding (0.0625-10 nM; 10 concentrations) to $5 \mathrm{HT}_{2 \mathrm{~A}} \mathrm{R}$ was measured at equilibrium in $500 \mu \mathrm{l}$ aliquots ( $50 \mathrm{mM}$ Tris- $\mathrm{HCl}$; $\mathrm{pH}$ 7.4) of membrane preparations (10-57 $\mu \mathrm{g}$ protein per tube), which were incubated at $37^{\circ} \mathrm{C}$ for $60 \mathrm{~min}$ as described previously (Gonzalez-Maeso et al, 2008). Nonspecific binding was determined in the presence of $10 \mu \mathrm{M}$ methysergide (Tocris Bioscience, Ellisville, $\mathrm{MO}$ ), and ranged from $27 \pm 2$ to $61 \pm 4 \%$ of total binding in all groups. The study was performed in two independent groups of animals; $n=8$ animals per genotype for each study.

\section{Drug Preparation and Administration}

Chlorpromazine, clozapine, haloperidol, ketanserin, and DOI were obtained from Sigma Aldrich (St Louis, MO). Olanzapine, quetiapine, and ziprasidone were obtained through the NIMH Chemical Synthesis and Drug Supply Program (Bethesda, MD). MDL-11939 was obtained from Tocris Bioscience (Ellisville, MO). Chlorpromazine and DOI were dissolved in saline. Olanzapine, quetiapine, and haloperidol were dissolved in a small amount of glacial acetic acid and further diluted in sterile water. Clozapine and MDL-11939 were dissolved in $\mathrm{HCl}$ and diluted in sterile water. Ketanserin was diluted in DMSO and sterile water. Ziprasidone was diluted in $45 \%$ 2-hydroxypropyl- $\beta$-cyclodextrin. Concentrated aliquots of each drug were stored at $-20^{\circ} \mathrm{C}$. Aliquots were thawed at $37^{\circ} \mathrm{C}$ and diluted to their final concentration in sterile saline on the day of testing. Solutions were buffered as necessary to achieve a final $\mathrm{pH}$ of 6.5-7.5. $K_{\mathrm{i}}$ determinations were generously provided by the National Institute of Mental Health's Psychoactive Drug Screening Program, Contract No. HHSN-271-2008-00025-C (NIMH PDSP; Bethesda, MD).

For each drug tested, vehicle was prepared in an identical manner without the addition of drug. Drug or vehicle was administered via intraperitoneal injection in a $10 \mathrm{ml} / \mathrm{kg}$ volume.

\section{Data Analysis}

Statistical analyses, including analysis of variance (ANOVA), Student's $t$-test, and standard error of the mean (SEM) were performed in SPSS (Chicago, IL) and Microsoft Excel. Locomotor activity and DOI-induced head-twitch behavior were evaluated using a two-way ANOVA. Behavioral assessment data were examined in SPSS using repeatedmeasures multivariate ANOVA (MANOVA) with treatment and genotype as a between-subjects factor and time as a repeated measure. Data are represented as means \pm SEM in all graphs.

\section{RESULTS}

We have previously reported that $E g r 3^{-1-}$ mice are resistant to the locomotor inhibitory effects of the antipsychotic medication clozapine ((Gallitano-Mendel et al, 2008), see online video at http://www.nature.com/npp/journal/v33/n6/ extref/1301505x3.mov). This response is not due to the baseline hyperactivity (a schizophrenia-like rodent phenotype) displayed by $\mathrm{Egr}^{-1-}$ mice as the animals do not show this response to the antipsychotic haloperidol. We have previously shown that haloperidol normalizes the hyperactivity of $\mathrm{Egr3}^{-1-}$ mice to WT vehicle-treated levels at a dosage that has no effect on the locomotor activity of WT mice, and higher dosages of haloperidol reduce the activity of both WT and $\mathrm{Egr}^{-/-}$mice to the same degree (Gallitano-Mendel et al, 2008). In contrast, clozapine profoundly suppresses the activity of WT mice at a dosage that reduces the hyperactivity of $E g r 3^{-1-}$ mice only to WT vehicle-treated levels (Gallitano-Mendel et al, 2008). Thus, the locomotor inhibition produced by haloperidol is not the same as that resulting from clozapine, and $\mathrm{Egr}^{-/-}$mice distinguish this difference.

In this study, we have employed a 'pharmacological dissection' approach, using increasingly selective drugs to target specific receptor subtypes in the clozapine binding profile, to identify the receptor abnormality that is responsible for the decreased sensitivity of $\mathrm{Egr3}^{-1-}$ mice to locomotor suppression by clozapine, compared with haloperidol. To identify drugs that mimic the effects of clozapine, we first established the dosage of each test drug that suppressed locomotor activity (ie, decreased activity below 1000 movements per $\mathrm{h}$ ) in a pilot group of WT mice 
(Supplementary Figure S1). We then tested whether that dosage also reduced the locomotor activity of $\mathrm{Egr}^{-1-}$ mice.

\section{Agents Selective for Receptors Commonly Associated with Sedation Fail to Replicate the Effect of SGAs in Egr3 $^{-1-}$ Mice}

We began by targeting the receptor systems to which the sedating effects of clozapine and other SGAs are commonly attributed: the histamine $\mathrm{H} 1$ receptor and $\alpha$-adrenergic receptors (Alves et al, 2010; Casey, 1997; Mengod et al, 1996; Parsons and Ganellin, 2006). Dose-response pilot experiments in WT C57Bl/6 mice (the background strain of $\mathrm{Egr3}^{-l-}$ mice) revealed that the selective $\mathrm{H} 1$ receptor antagonist pyrilamine (also known as mepyramine) does not reduce locomotor activity, even at doses up to $50 \mathrm{mg} / \mathrm{kg}$, the highest dose used in mice found in the literature (Figure 1 and Table 1) (Parsons and Ganellin, 2006; Shishido et al, 1991). A pilot study with diphenhydramine, another relatively selective $\mathrm{H} 1$ antagonist (Parsons and Ganellin, 2006), yielded similar results (Table 1). Promethazine, a less selective $\mathrm{H} 1$ receptor antagonist (Wishart et al, 2008; Wishart et al, 2006) and member of the phenothiazine family, suppressed activity at the highest administered dose $(50 \mathrm{mg} / \mathrm{kg})$, but did so equally in both WT control and $\mathrm{Egr3}^{--}$mice, failing to reproduce the response to clozapine (Table 1). Tests with terazosin, an $\alpha 1$-adrenergic receptor antagonist, and medetomidine, an $\alpha 2$-specific agonist used as a sedative in veterinary medicine (Alves et al, 2010), likewise showed similar levels of locomotor suppression in $\mathrm{Egr}^{-1-}$ and WT mice (Table 1). These findings indicate that neither $\mathrm{H} 1$ histamine receptors nor $\alpha$-adrenergic receptors alone are responsible for the resistance of $\mathrm{Egr3}^{-1-}$ mice to the locomotor inhibitory effects of clozapine.

\section{Egr3 $^{-1-}$ Mice Exhibit Resistance to Locomotor Suppression by SGAS, but not FGAS}

As the receptors commonly implicated in sedation did not appear to be responsible for the resistance of $\mathrm{Egr}^{-1-}$ mice to this effect of clozapine, we returned to our earlier finding that $\mathrm{Egr3}^{-I-}$ mice do not display resistance to the locomotor inhibitory effects of the FGA haloperidol (Gallitano-Mendel et al, 2008). In other words, haloperidol reduces the hyperactivity of $E g r 3^{-l-}$ mice to normal levels at a dosage that does not affect the activity of WT mice, and higher doses of the medication inhibit activity in WT and Egr $^{-1-}$ mice in an equivalent manner (Gallitano-Mendel et al, 2008). We hypothesized that this may be because haloperidol is a high potency antipsychotic that is also less sedating than other FGA medications. We therefore tested whether chlorpromazine $(0,5$, and $10 \mathrm{mg} / \mathrm{kg})$, a low-potency FGA that is highly sedating, would produce a similar behavioral effect on $\mathrm{Egr}^{-I-}$ mice. Figure 2a shows that chlorpromazine reduced the activity of $E g r 3^{-1-}$ mice at the same dosage as WT mice, an effect similar to that of haloperidol, and markedly different than that of clozapine. A two-way ANOVA revealed a main effect of chlorpromazine $(\mathrm{F}(2,54)=21.1 ; p<0.001)$ and genotype $(\mathrm{F}(1,54)=45.5$; $p<0.001)$ on locomotor activity, and a treatment by genotype interaction $(\mathrm{F}(2,54)=7.1 ; p<0.05)$. Figure $2 \mathrm{~b}$

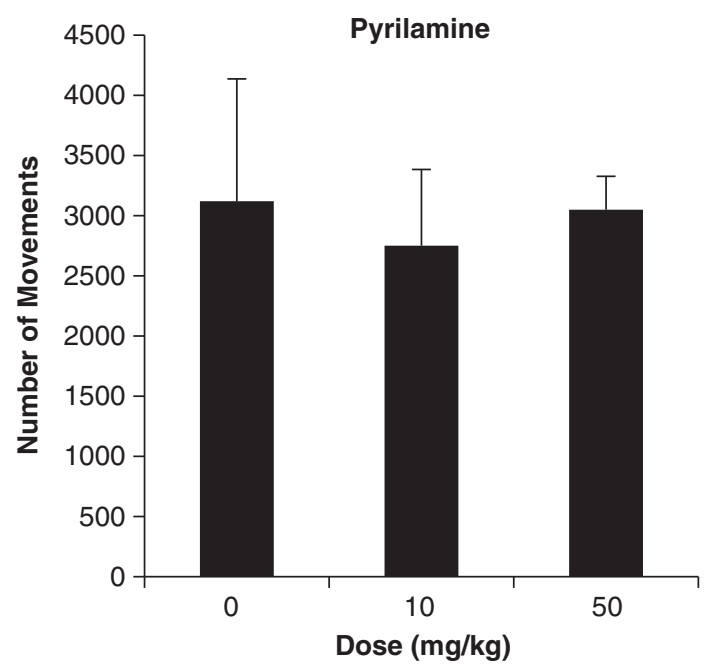

Figure I Histamine $H_{1}$ antagonism is not responsible for resistance of Egr3-deficient $\left(\mathrm{Egr}^{-l-}\right)$ mice to locomotor suppression by clozapine. Locomotor activity was monitored for $60 \mathrm{~min}$ in wild-type (WT) mice following administration of highly specific $\mathrm{H}_{\text {। }}$ receptor antagonist pyrilamine. Pyrilamine was not sedating at 10 or $50 \mathrm{mg} / \mathrm{kg}$, the highest dose reported in the literature (Roth, 2008) ( $n=3$ per group)

shows that each dose of chlorpromazine reduced activity to a similar degree, on average, in both WT $(77 \%$ with $5 \mathrm{mg} / \mathrm{kg}$ and $95 \%$ with $10 \mathrm{mg} / \mathrm{kg}$ ) and $E g r 3^{-l-}$ mice $(74 \%$ with $5 \mathrm{mg} / \mathrm{kg}$ and $89 \%$ with $10 \mathrm{mg} / \mathrm{kg}$ ) (differences were not significant by Bonferroni-corrected Student's $t$-test). On visual inspection both WT control and $E g r 3^{-1-}$ mice appeared immobile following the highest dose $(10 \mathrm{mg} / \mathrm{kg})$ of chlorpromazine (Supplementary Video S2).

We then repeated this assay with other SGAs to assess whether $\mathrm{Egr}^{-1-}$ mice would show the same locomotor response to other medications within the same classification as clozapine. Figure $3 \mathrm{a}$ shows that olanzapine, an SGA designed to mimic the receptor binding activity of clozapine, suppressed the locomotor activity of WT mice to nearly zero, while the activity of $\mathrm{Egr}^{-1-}$ mice was decreased only to vehicle-treated WT levels (also see Supplementary Video S3). This result was identical to that of clozapine (Gallitano-Mendel et al, 2008). A two-way ANOVA evaluating locomotor activity following administration of olanzapine $(0,1,2$, and $3 \mathrm{mg} / \mathrm{kg}$ ) revealed a main effect of treatment $(\mathrm{F}(3,56)=17.7 ; p<0.001)$ and genotype $(\mathrm{F}(1,56)=155.7 ; p<0.001)$, and a treatment by genotype interaction $(\mathrm{F}(3,56)=4.6 ; p<0.01)$. Figure $3 \mathrm{~b}$ shows that each dose of olanzapine reduced the activity more in WT mice than in $\mathrm{Egr}^{-1-}$ mice. Compared to vehicle-treated mice, a $3 \mathrm{mg} / \mathrm{kg}$ dose of olanzapine reduced activity by $98 \%$, on average, in WT mice, but only $51 \%$ in $\mathrm{Egr}^{-1-}$ mice $(p<0.001$, Student's $t$-test).

Similar analyses following administration of two additional SGAs replicated these effects. Figures $3 \mathrm{c}-\mathrm{f}$ show that $\mathrm{Egr}^{-1-}$ mice are similarly resistant to the locomotor suppressive effects of quetiapine and ziprasidone as to clozapine and olanzapine. The two-way ANOVA following administration of quetiapine $(0,10$, and $20 \mathrm{mg} / \mathrm{kg})$ revealed a main effect of treatment $(\mathrm{F}(2,36)=20.4 ; p<0.001)$ and genotype $(\mathrm{F}(1,36)=92.5 ; p<0.001)$, and a treatment by 

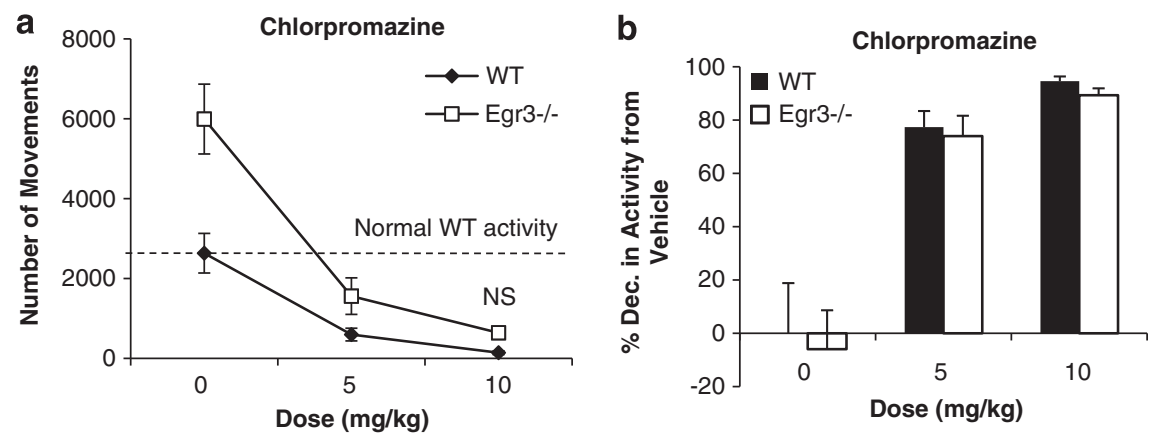

Figure 2 First-generation antipsychotics (FGAs) reduce activity to a similar degree in Egr3-deficient (Egr $3^{-{ }^{-}}$) and wild-type (WT) mice. The locomotor activity of Egr $3^{-1-}$ and WT mice was monitored for 60 min following administration of chlorpromazine, a low-potency, highly sedating FGA. As previously reported with haloperidol (Gallitano-Mendel et al., 2008), Egr3 ${ }^{-1-}$ mice demonstrate a similar susceptibility to locomotor suppression by chlorpromazine as WT controls (see also Supplementary Video S2). (a) Vehicle-treated Egr $3^{-1-}$ mice are hyperactive in comparison to vehicle-treated WT mice. Chlorpromazine reduced locomotor activity in a dose-dependent manner to a similar degree in both Egr $3^{-1-}$ and WT mice ( $n=10$ per group). (b) The average activity of vehicle-treated mice for each genotype was used to calculate the percent decrease from basal activity for each animal (see Methods). The average percent decrease in activity is presented for both $\mathrm{Egr}^{-1-}$ and WT mice treated with either 0 , 5, or $10 \mathrm{mg} / \mathrm{kg}$ chlorpromazine.

genotype interaction $(\mathrm{F}(2,36)=4.0 ; p<0.05)$ (Figure $3 \mathrm{c})$. Figure $3 \mathrm{~d}$ shows that $20 \mathrm{mg} / \mathrm{kg}$ of quetiapine reduced activity more in WT than Egr3 ${ }^{-I-}$ mice when compared to vehicle-treated mice of the respective genotype $(p<0.001$, Student's $t$-test). Ziprasidone treatment $(0,2.5$, and $5 \mathrm{mg} / \mathrm{kg})$ also revealed main effects of treatment $(\mathrm{F}(2,41)=18.1$; $p<0.001)$ and genotype $(\mathrm{F}(1,41)=62.6, p<0.001)$, and $\mathrm{a}$ treatment by genotype interaction $(\mathrm{F}(2,41)=4.5, p<0.05)$ (Figure $3 \mathrm{e}$ ). Figure $3 \mathrm{f}$ shows that, like the other SGAs, in comparison to vehicle-treated mice, each dose of ziprasidone reduce the activity of WT mice to a greater degree than the activity of $\mathrm{Egr3}^{-1-}$ mice $(p<0.005$ for $2.5 \mathrm{mg} / \mathrm{kg}$ dose, $p<0.001$ for $5 \mathrm{mg} / \mathrm{kg}$ dose, Student's $t$-test). These findings suggest that $E g r 3^{-/-}$mice differ from WT mice in their response to the locomotor suppressive effect of SGAs, but not to that of FGAs.

The SGAs differ from FGAs in producing a significantly lower incidence of extra-pyramidal side effects (Pierre, 2005). This response in mice is identified by 'stereotypic movements' (or 'stereotypy'). As the activity-monitoring test we employed does not differentiate sedation from other causes of immobility, we evaluated the behavioral response of $E g r 3^{-1-}$ and WT mice to the SGA clozapine, and the FGA haloperidol, using rating scales for drowsiness, motor impairment, and stereotypic behaviors. Figures $4 \mathrm{a}$ and $\mathrm{b}$ show that WT mice are significantly more sensitive to both the drowsiness and motor impairment caused by clozapine than are $E g r 3^{-1-}$ mice. Repeated-measures MANOVA revealed a main effect of both treatment and genotype and a treatment by genotype interaction on drowsiness $(\mathrm{F}(1,28)=21.5 \quad(p<0.001)$, $\mathrm{F}(1,28)=7.6 \quad(p<0.05), \quad \mathrm{F}(1,28)=10.4 \quad(p<0.005)$, respectively) and motor impairment $(\mathrm{F}(1,28)=33.8 \quad(p<0.001)$, $\mathrm{F}(1,28)=6.7(p<0.05), \mathrm{F}(1,28)=6.7(p<0.05))$. In contrast, WT and $E g r 3^{-1-}$ mice did not differ in the number of stereotypic movements they displayed following administration of clozapine (Figure 4c). Analysis of stereotypy data (Figure 4c) revealed a main effect of clozapine treatment $(\mathrm{F}(1,28)=15.5 \quad(p<0.005))$, but not genotype $(p>0.05)$. Within-subjects analysis revealed a time by genotype interaction on stereotypy $(\mathrm{F}(1,28)=5.2 ; p<0.05)$, indicating that the two genotypes varied in the timing of their stereotypic movements across the test period, with WT mice displaying more stereotypy at 30 than $60 \mathrm{~min}$, and $E g r 3^{-1-}$ mice showing a more level number of stereotypic movements between the two time points. However, this timing effect is unlikely to account for drug-induced differences in locomotor-activity between $\mathrm{Egr3}^{-\mathrm{P}_{-}}$and WT mice as both time points are included in the $60 \mathrm{~min}$ activity monitoring session.

Like clozapine, haloperidol also induced a different degree of drowsiness in Egr3 ${ }^{-1-}$ mice than in WT mice. However, the effect was the opposite to that of clozapine, with grr $^{-I-}$ mice showing more drowsiness than WT mice following haloperidol administration (Figure 4d). Haloperidol caused motor impairment in both $\mathrm{Egr3}^{-1-}$ and WT mice, although the difference in the response of the two genotypes was not evident until $60 \mathrm{~min}$ after drug administration (Figure 4e). Repeated-measures MANOVA on haloperidol treatment revealed a main effect of both treatment and genotype on drowsiness $(\mathrm{F}(1,32)=33.8$ $(p<0.001)$ and $\mathrm{F}(1,32)=17.2(p<0.001)$, respectively $)$ and motor impairment $(\mathrm{F}(1,32)=116.3 \quad(p<0.001)$ and $\mathrm{F}(1,32)=4.6(p<0.05)$, respectively $)$ and a treatment by genotype interaction on drowsiness $(\mathrm{F}(1,32)=15.5$ $(p<0.001))$, but not on motor impairment $(p>0.05)$. Analysis of stereotypy data (Figure $4 \mathrm{f}$ ) revealed a main effect of treatment $(\mathrm{F}(1,32)=70.0(p<0.001))$, but not of genotype $(\mathrm{F}(1,32)=0.007(p=0.9))$. Within-subject analysis revealed a main effect of time on drowsiness $(\mathrm{F}(1,32)=5.3 ; p<0.05)$ and a three-way time by dose by genotype interaction $(\mathrm{F}(1,32)=5.33 ; p<0.05)$. These results indicate that $\mathrm{Egr}^{-1-}$ mice differ from WT mice in their sensitivity to sedating and motor-impairing effects of antipsychotic medications, but they do not differ in their sensitivity to the stereotypic effects of these drugs. This suggests that the different motor effects of FGAs vs SGAs on $\mathrm{Egr}^{-l-}$ mice are not stereotypic in nature.

\section{HT ${ }_{2 \mathrm{~A}} \mathrm{R}$ Antagonists Parallel the Effect of Clozapine on Egr3 $^{-7-}$ Mice}

One of the leading features distinguishing SGAs from FGAs is the high affinity SGAs display for the $5 \mathrm{HT}_{2 \mathrm{~A}} \mathrm{R}$ (Meltzer et al, 2003). We therefore tested whether this receptor was responsible for the resistance of $\mathrm{Egr}^{-1-}$ mice to the 

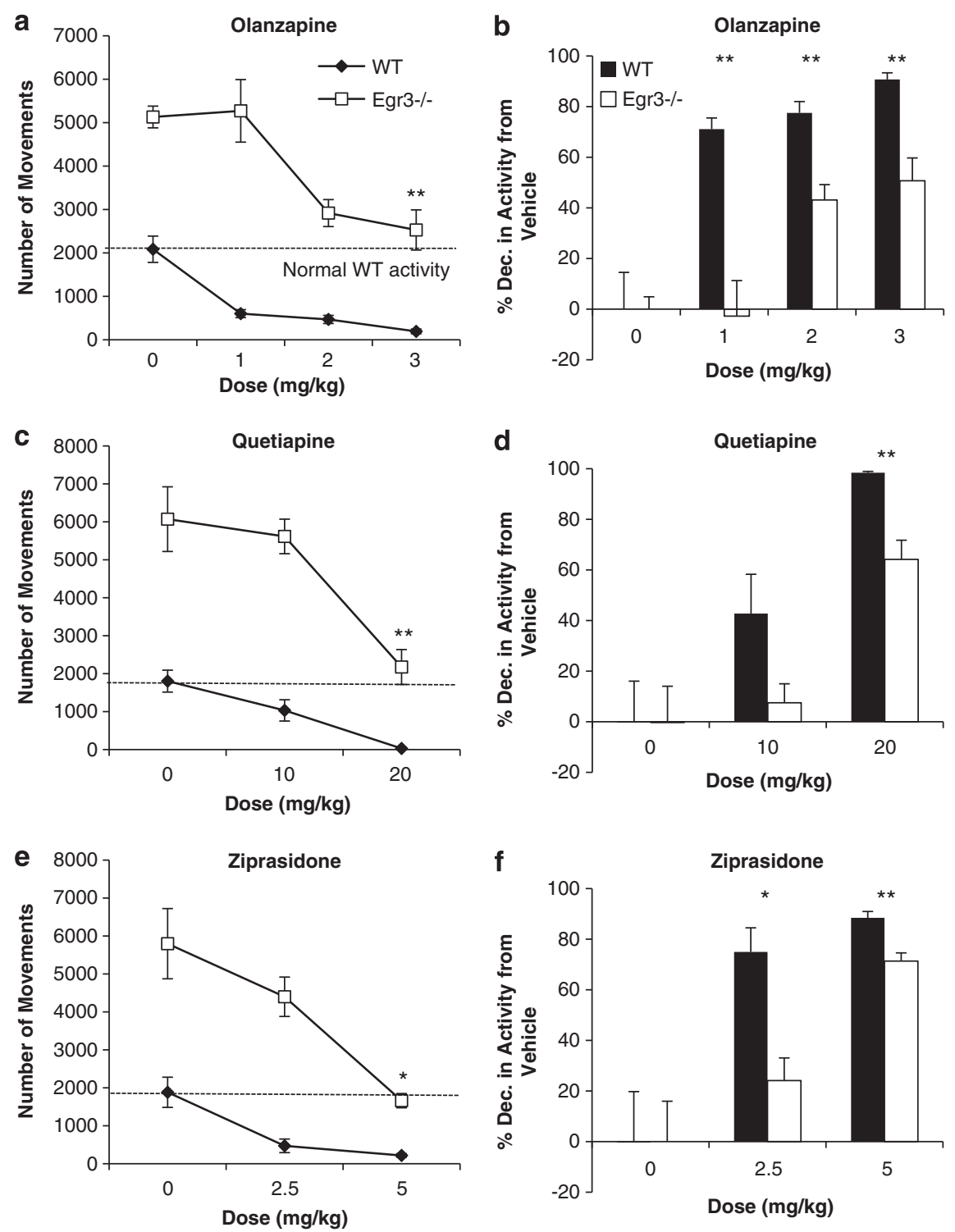

Figure 3 Egr3-deficient $\left(E g r 3^{-l-}\right.$ ) mice are resistant to locomotor inhibition by second-generation antipsychotic agents (SGAs). The locomotor activity of $\mathrm{Egr}^{-1-}$ and WT mice was monitored for $60 \mathrm{~min}$ following administration of SGAs. (a) Olanzapine suppressed the activity of WT controls at a dosage of $\mathrm{I} \mathrm{mg} / \mathrm{kg}$, while a dosage of $3 \mathrm{mg} / \mathrm{kg}$ reduced the activity of Egr $3^{-1-}$ mice to normal WT activity levels ( $n=8$ per group) (see also Supplementary Video S3). (b) The average activity of vehicle-treated mice for each genotype was used to calculate the percent decrease from basal activity for each animal (see Materials and Methods). The average percent decrease is presented for both Egr $3^{-1-}$ and WT mice treated with 0, I, 2, or $3 \mathrm{mg} / \mathrm{kg}$ olanzapine. (c) Quetiapine reduced the activity of Egr $3^{-1}$ mice to vehicle-treated WT activity levels, while abolishing almost all locomotor activity in WT mice, at $20 \mathrm{mg} / \mathrm{kg}(n=7 \mathrm{per}$ group). (d) The average percent decrease in activity from vehicle group is presented for both Egr $3^{-1-}$ and WT mice treated with 0,10 , or $20 \mathrm{mg} / \mathrm{kg}$ quetiapine. (e) Ziprasidone (2.5 mg/kg) suppressed the activity of WT mice, while $5 \mathrm{mg} / \mathrm{kg}$ was required to reduce the hyperactivity of Egr $3^{-/-}$mice to normal WT levels ( $n=10$ per group). (f) The average percent decrease in activity from vehicle group is presented for both Egr $3^{-1-}$ and WT mice treated with $0,2.5$, or 5 mg/kg ziprasidone. *Significant post hoc comparisons of simple main effects between Egr $3^{-1-}$ and WT mice at the dose leading to an extreme suppression in activity in WT controls ( $a, c$, and e), or Student's t-test after Bonferroni correction for multiple comparisons ( $b$, $d$, and $f)(* p<0.05$; $* * p<0.00$ I).

locomotor suppressive effects of these medications by examining the effect of drugs with relatively selective affinity for the $5 \mathrm{HT}_{2 \mathrm{~A}} \mathrm{R}$. First, we examined the effect of the $5 \mathrm{HT}_{2 \mathrm{~A}} \mathrm{R}$ antagonist ketanserin. Figure $5 \mathrm{a}$ shows that $5 \mathrm{mg} / \mathrm{kg}$ ketanserin suppressed locomotor activity in WT mice, while the locomotor hyperactivity of $\mathrm{Egr}^{-1-}$ mice was not even reduced to vehicle-treated WT levels. A twoway ANOVA on activity following treatment with $5 \mathrm{HT}_{2 \mathrm{~A}} \mathrm{R}$ antagonist ketanserin $(0,2.5$, and $5 \mathrm{mg} / \mathrm{kg})$ revealed a main effect of treatment $(\mathrm{F}(2,42)=4.5 ; p<0.05)$ and genotype
$(\mathrm{F}(1,42)=65.8 ; p<0.001)$, and no treatment by genotype interaction $(F(2,42)=1.1 ; p>0.05)$. Figure $5 b$ shows that ketanserin reduced activity more in WT mice than $\mathrm{Egr3}^{-1-}$ mice. Compared to vehicle-treated mice, a $5 \mathrm{mg} / \mathrm{kg}$ dose of ketanserin reduced activity by $78 \%$, on average, in WT mice, but only $17 \%$ in $\mathrm{Egr}^{-1-}$ mice $(p<0.001$, Student's $t$-test).

Ketanserin binds with high affinity to $5 \mathrm{HT}_{2 \mathrm{~A}} \mathrm{Rs}$, but also binds to other serotonin receptors, as well as $\mathrm{H} 1$ and D1 dopamine receptors, with lower affinity, as summarized in 

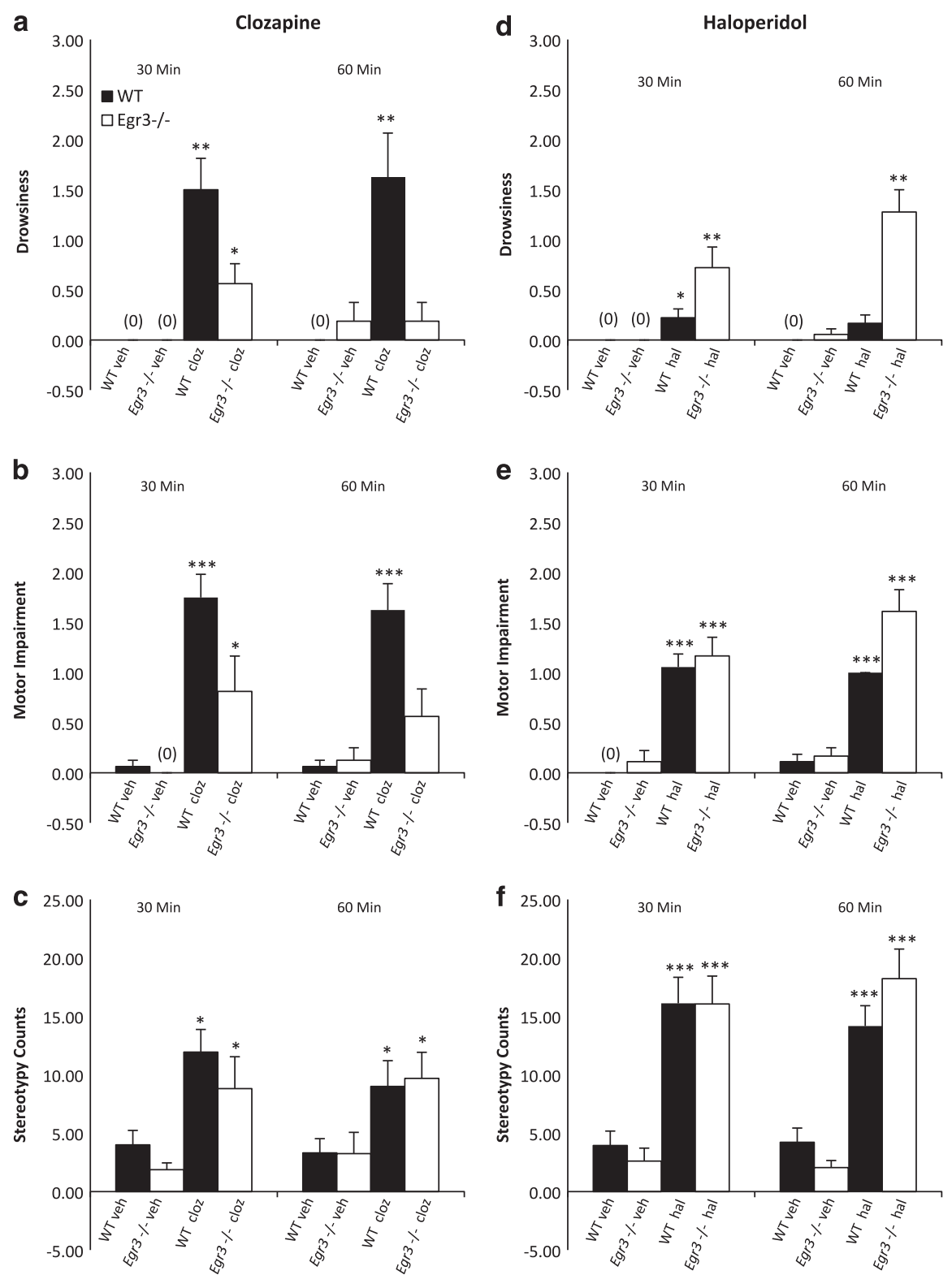

Figure 4 Stereotypic behavior does not account for the differential response of Egr3-deficient $\left(E g r 3^{-1-}\right.$ ) mice to first-generation antipsychotics (FGAs) vs second-generation antipsychotics (SGAs). Drowsiness, motor impairment, and stereotypy scores were assessed at 30 and 60 min following administration of the drug (clozapine, $7 \mathrm{mg} / \mathrm{kg}$, a, b, and c; or haloperidol, $3 \mathrm{mg} / \mathrm{kg}, \mathrm{d}, \mathrm{e}$, and f) or corresponding vehicle. Egr $3^{-1-}$ and wild-type (WT) mice responded differently to clozapine than to haloperidol in measures of drowsiness $(a, d)$ and motor impairment (b, e), but not stereotypy (c, f) ( $n=8$ per group for clozapine; $n=9$ per group for haloperidol). *Significant comparisons between vehicle and drug treatment groups within genotype $(* p<0.05 ; * * 2<0.0$ I; **** $p<0.005$; by Student's t-test).

Table 2. We therefore also examined the effect of the potent, selective $5 \mathrm{HT}_{2 \mathrm{~A}} \mathrm{R}$ antagonist MDL-11939 $(0,2.5,5$, and $10 \mathrm{mg} / \mathrm{kg}$ ). Figure $5 \mathrm{c}$ shows that $5 \mathrm{mg} / \mathrm{kg}$ of MDL-11939 produced the same locomotor inhibitory effect on WT mice as ketanserin. An additional increase in dosage (to $10 \mathrm{mg} / \mathrm{kg}$ ) did not further suppress locomotor activity in either WT or $\mathrm{Egr3}^{-1-}$ mice. The two-way ANOVA revealed a main effect of treatment $(\mathrm{F}(3,56)=63.8 ; p<0.001)$ and genotype $(\mathrm{F}(1,56)=4.5 ; p<0.01)$, but no treatment by genotype interaction $(\mathrm{F}(3,56)=0.7 ; p>0.05)$. While the locomotor suppression produced by MDL-11939 in WT mice was not as extreme as that of the highest doses of antipsychotics, the resistance of $\mathrm{Egr}^{-1-}$ mice to its suppressive effect was greater than to the SGAs, as MDL-11939 (up to $10 \mathrm{mg} / \mathrm{kg}$ ) failed to reduce the hyperactivity of $\mathrm{Egr}^{-1-}$ mice to normal WT levels. Visual inspection of animals revealed a marked difference in activity between treated WT and $\mathrm{Egr}^{-1-}$ mice (Supplementary Video S4).

\section{$\mathrm{Egr3}^{-1-}$ Mice have a Deficit of $5 \mathrm{HT}_{2 \mathrm{~A}} \mathrm{Rs}$ in the Prefrontal Cortex}

To determine whether dysfunction of $5 \mathrm{HT}_{2 \mathrm{~A}} \mathrm{Rs}$ may be the mechanism underlying the resistance of $\mathrm{Egr3}^{--}$mice to the locomotor inhibitory effects of $5 \mathrm{HT}_{2 \mathrm{~A}} \mathrm{R}$-specific agents, we conducted a radioligand binding assay to determine the 

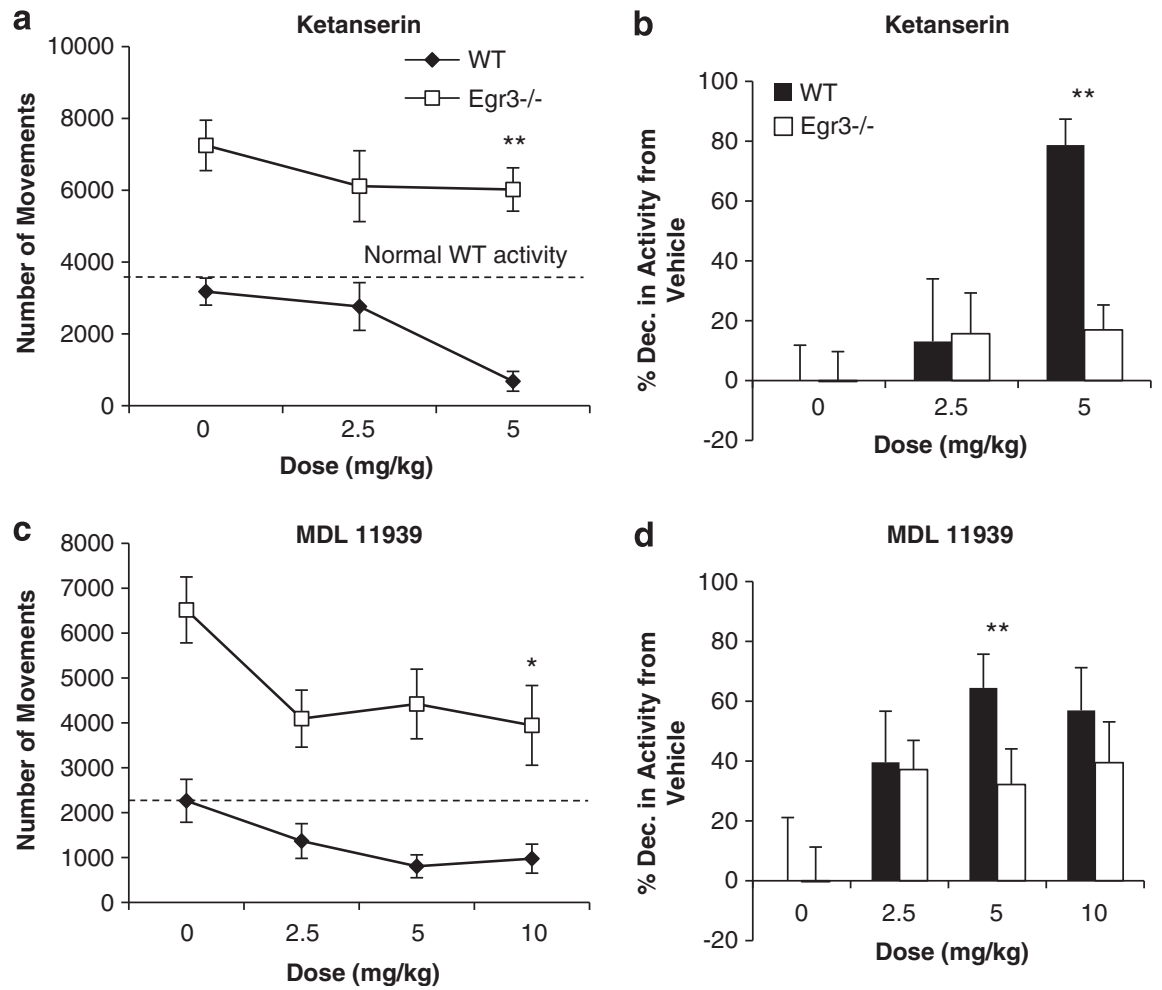

Figure 5 Serotonin $2 \mathrm{~A}$ receptor $\left(5 \mathrm{HT}_{2 \mathrm{~A}} \mathrm{R}\right)$ antagonists suppress the locomotor activity of wild-type (WT), but not Egr3-deficient (Egr $\left.3^{-1-}\right)$ mice. Locomotor activity was monitored for 60 min following administration of $5 \mathrm{HT}_{2 \mathrm{~A}} \mathrm{R}$-specific agents or vehicle. (a) Ketanserin suppresses the locomotor activity of WT mice at $5 \mathrm{mg} / \mathrm{kg}$, a dose that decreases the hyperactivity of $E g r 3^{-1-}$ mice, but does not reduce it to normal WT levels ( $n=7-9$ per group). (b) The average activity of vehicle-treated mice for each genotype was used to calculate the percent decrease from basal activity for each animal (see Methods). The average percent decrease in activity from vehicle group is presented for both Egr $3^{-1-}$ and WT mice treated with 0, 2.5, or 5.0 mg/kg ketanserin. (c) MDL$11939(10 \mathrm{mg} / \mathrm{kg})$ suppresses the activity in WT mice, but fails to reduce the hyperactivity of Egr $3^{-1-}$ mice to normal WT activity levels $(n=8$ per group) (see also Supplementary Video S4). (d) The average percent decrease in activity from vehicle group is presented for both Egr $3^{-1-}$ and WT mice treated with $0,2.5,5$, and $10 \mathrm{mg} / \mathrm{kg}$ MDL- I 1939. *Significant post hoc comparisons of simple main effects between Egr $3^{-1-}$ and WT mice at the dose leading to an extreme reduction in activity in WT controls ( $a$ and $c$ ) or Student's $t$-test after Bonferroni correction for multiple comparisons (b and d) $(* p<0.005$; *** $<<0.00$ I).

level of expression of $5 \mathrm{HT}_{2 \mathrm{~A}} \mathrm{R}$ in $E g r 3^{-1-}$ mice. In the murine brain, $5 \mathrm{HT}_{2 \mathrm{~A}} \mathrm{Rs}$ are expressed in the frontal cortex along an anterior to posterior gradient, and show very little expression in other brain regions (Lein et al, 2007; Meltzer et al, 2010). The PFC expresses high levels of $5 \mathrm{HT}_{2 \mathrm{~A}} \mathrm{Rs}$, and is also a key region implicated in schizophrenia pathogenesis in humans. We therefore dissected this region to compare receptor levels in $E g r 3^{-I-}$ and WT using radioligand binding with $\left[{ }^{3} \mathrm{H}\right]$ ketanserin, a selective $5 \mathrm{HT}_{2 \mathrm{~A}} \mathrm{R}$ ligand (Figure 6a). There was no change in the receptor binding affinity. Figure $6 \mathrm{~b}$ shows that the maximum number of $5 \mathrm{HT}_{2 \mathrm{~A}} \mathrm{R} /\left[{ }^{3} \mathrm{H}\right]$ ketanserin binding sites is reduced by nearly $70 \%$ in the prefrontal cortex of $\mathrm{Egr}^{-1-}$ mice compared with WT controls $(\mathrm{F}(2,170)=14.77 ; p<0.001$, Student's $t$-test).

$\mathrm{Egr}^{-1-}$ mice also displayed a decreased behavioral response to DOI $(1 \mathrm{mg} / \mathrm{kg})$, a $5 \mathrm{HT}_{2 \mathrm{~A}} \mathrm{R}$ agonist that produces a distinctive head-twitch response in WT mice (Darmani et al, 1990; Gonzalez-Maeso et al, 2003) (Figure 6c). The two-way ANOVA revealed a main effect of treatment $(\mathrm{F}(1,20)=33.1 ; p<0.001)$ and a treatment by genotype interaction $(\mathrm{F}(1,20)=9.1 ; p<0.01)$. In summary, these results demonstrate a functional deficit of membranebound $5 \mathrm{HT}_{2 \mathrm{~A}} \mathrm{Rs}$ in the PFC of $\mathrm{Egr3}^{-/-}$mice.

\section{DISCUSSION}

The aim of this study was to elucidate the mechanism underlying our previously published observation that $\mathrm{Egr}^{-I-}$ mice are resistant to the locomotor suppression produced in WT mice by clozapine, a uniquely effective antipsychotic medication that remains one of the leading treatments for schizophrenia (Gallitano-Mendel et al, 2008; Kane et al, 1988). In addition, this study simultaneously addressed our larger objective, to identify a downstream effector of Egr3. Such a gene would be a potential next step in our hypothesized biological pathway influencing schizophrenia susceptibility.

In the past decade, human genetics studies have identified numerous genes that are associated with risk to develop schizophrenia, a severe mental illness that affects $1 \%$ of the world's population. However, any individual gene is only able to account for a small percentage of illness risk (Allen et al, 2008; Owen et al, 2010). One way to unite multiple candidate genes conceptually is to identify those which act in a common biological pathway. EGR3 is an immediateearly gene transcription factor that is regulated downstream of three major proteins implicated in schizophrenia susceptibility (neuregulin 1; (Hippenmeyer et al, 2002; 

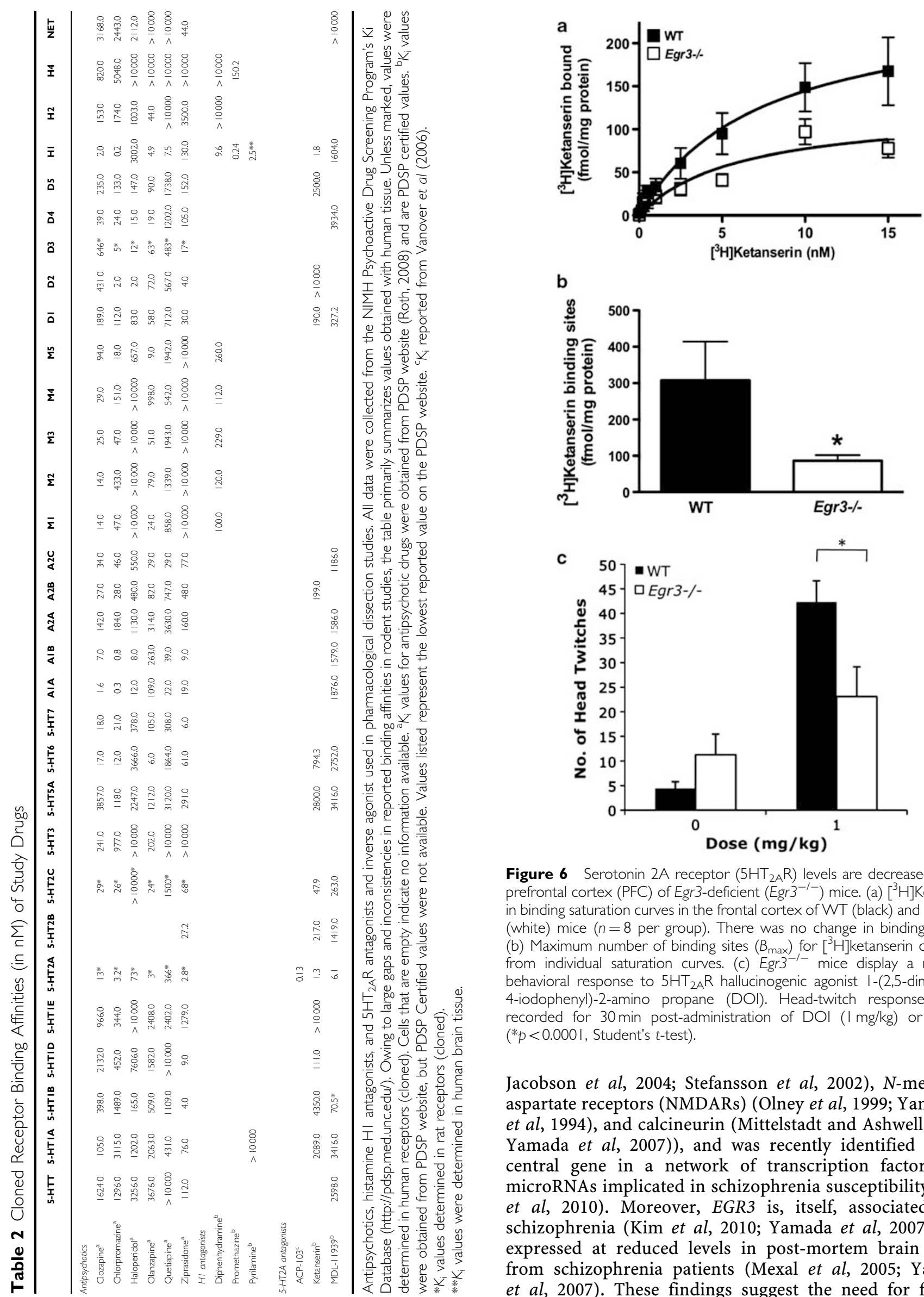

Figure 6 Serotonin $2 \mathrm{~A}$ receptor $\left(5 \mathrm{HT}_{2 \mathrm{~A}} \mathrm{R}\right)$ levels are decreased in the prefrontal cortex (PFC) of Egr3-deficient $\left(\mathrm{Egr}^{-1-}\right.$ ) mice. (a) $\left.{ }^{3} \mathrm{H}\right]$ Ketanserin binding saturation curves in the frontal cortex of WT (black) and Egr3 ${ }^{-1-}$ (white) mice ( $n=8$ per group). There was no change in binding affinity. (b) Maximum number of binding sites $\left(B_{\max }\right)$ for $\left[{ }^{3} \mathrm{H}\right]$ ketanserin obtained from individual saturation curves. (c) Egr $3^{-1-}$ mice display a reduced behavioral response to $5 \mathrm{HT}_{2 \mathrm{~A}} \mathrm{R}$ hallucinogenic agonist I-(2,5-dimethoxy 4-iodophenyl)-2-amino propane (DOI). Head-twitch responses were recorded for $30 \mathrm{~min}$ post-administration of DOI $(1 \mathrm{mg} / \mathrm{kg})$ or vehicle $(* 0<000$ I, Student's t-test).

Jacobson et al, 2004; Stefansson et al, 2002), N-methyl D aspartate receptors (NMDARs) (Olney et al, 1999; Yamagata et al, 1994), and calcineurin (Mittelstadt and Ashwell, 1998; Yamada et al, 2007)), and was recently identified as the central gene in a network of transcription factors and microRNAs implicated in schizophrenia susceptibility (Guo et al, 2010). Moreover, EGR3 is, itself, associated with schizophrenia (Kim et al, 2010; Yamada et al, 2007), and expressed at reduced levels in post-mortem brain tissue from schizophrenia patients (Mexal et al, 2005; Yamada et al, 2007). These findings suggest the need for further 
investigations of a potential role for EGR3, and the biological pathway of genes in which it functions, in psychotic disorders.

Our 'pharmacological dissection' approach proved successful in revealing that $5 \mathrm{HT}_{2 \mathrm{~A}} \mathrm{R}$-specific antagonists parallel the activity of clozapine in suppressing the locomotor activity of WT mice at dosages that fail to reduce the activity of $E g r 3^{-I-}$ mice below normal WT activity levels. This is not due to the basal hyperactivity of $\mathrm{Egr3}^{-}$mice, as FGAs haloperidol (previously reported) and chlorpromazine (Figure 2) suppress the locomotor activity of $E g r 3^{-1-}$ mice at the same dosage as WT mice.

We hypothesized that a defect in the function of $5 \mathrm{HT}_{2 \mathrm{~A}} \mathrm{Rs}$ in the $E g r 3^{-1-}$ mice could explain their differential sensitivity to $5 \mathrm{HT}_{2 \mathrm{~A}} \mathrm{R}$ antagonists. Indeed, receptor binding studies using the $5 \mathrm{HT}_{2 \mathrm{~A}} \mathrm{R}$-selective ligand ketanserin revealed a nearly $70 \%$ reduction in $5 \mathrm{HT}_{2 \mathrm{~A}} \mathrm{R}$ activity in the PFC of $\mathrm{Egr}^{-1-}$ mice (Figure $6 \mathrm{a}$ and b). This reduction of receptors corresponded with the results of a functional assay, the head-twitch response to the $5 \mathrm{HT}_{2 \mathrm{~A}} \mathrm{R}$ agonist DOI (figure 6c), a drug-induced behavior that is absent in $5 \mathrm{HT}_{2 \mathrm{~A}} \mathrm{R}$ knockout mice. Thus, it appears that the reduced sensitivity of $\mathrm{Egr3}^{-1-}$ mice to the locomotor suppressive effects of clozapine and other SGAs may be a result of decreased levels of $5 \mathrm{HT}_{2 \mathrm{~A}} \mathrm{Rs}$ in the brains of the mice. Further investigation of the relative affinities of the FGAs and SGAs tested (using values from the PDSP website (Roth, 2008) and Table 2) indicated that the ratio of $5 \mathrm{HT}_{2 \mathrm{~A}} \mathrm{R}$ to D2R binding affinity best correlated with the locomotor inhibitory response of $\mathrm{Egr3}^{-1-}$ mice.

Findings in our animal model are notable as numerous studies have identified deficits in $5 \mathrm{HT}_{2 \mathrm{~A}} \mathrm{R}$ levels in the brains of schizophrenia patients (Dean and Hayes, 1996; Erritzoe et al, 2008; Garbett et al, 2008; Hurlemann et al, 2008; Lopez-Figueroa et al, 2004; Matsumoto et al, 2005; Ngan et al, 2000; Rasmussen et al, 2010; Serretti et al, 2007). Moreover, the HTR2A gene, which encodes the $5 \mathrm{HT}_{2 \mathrm{~A}} \mathrm{R}$, is a leading candidate schizophrenia gene (Allen et al, 2008). Thus, the deficit of $5 \mathrm{HT}_{2 \mathrm{~A}} \mathrm{R}$ in $E g r 3^{-l-}$ mice suggests a possible mechanism through which EGR3 (itself a candidate schizophrenia gene) may influence susceptibility to this mental illness. Furthermore, this finding suggests that the $5 \mathrm{HT}_{2 \mathrm{~A}} \mathrm{R}$ may act downstream of EGR3 in what we hypothesize to be a biological pathway of genes influencing schizophrenia risk.

\section{Insights into the Mechanisms of SGA-Induced Locomotor Suppression}

To date, the precise mechanism by which clozapine exerts its antipsychotic effects remains unclear. Similarly, the etiology of side effects, such as sedation and weight gain, are also uncertain. Despite this, the sedating effect of clozapine has frequently been attributed to antagonism of $\mathrm{H} 1$ histamine receptors (Casey, 1997; Mengod et al, 1996; Stahl, 2008). Our results suggest that this is not the case in C57BL/ 6 mice, as selective $\mathrm{H} 1$ antagonists fail to reduce WT locomotor activity even at the highest doses reported used in mice in the literature (Figure 1 and Table 1) (Parsons and Ganellin, 2006; Shishido et al, 1991). These findings suggest the possibility that selective antagonism of $\mathrm{H} 1$ receptors may not be the mechanism responsible for the sedating effect of SGAs in humans either.

However, it is possible that sedation in humans may differ from the locomotor suppression we see in mice. Species differences in the molecular regulation of psychoactive medications have been reported (Gershon et al, 2011). Further investigation in primates and humans are needed to assess whether these results translate across species. Alternatively, $\mathrm{H} 1$ antagonism may have a different effect in combination with drug activity at other receptors than it does alone. In fact, studies investigating low-dose administration of psychiatric medications are aimed at determining the relative influence of $\mathrm{H} 1$ receptors $v s$ other receptors involved in brain activation, in the sedating characteristics of these medications (Casey (1997) and references therein).

Instead, our findings suggest that the locomotor suppressive effect of SGAs in mice may result, at least in part, from the binding of these medications to $5 \mathrm{HT}_{2 \mathrm{~A}} \mathrm{Rs}$. Our data demonstrate that drugs which selectively target this receptor, ketanserin and MDL-11939 (Figure 5), parallel the effect of clozapine, and other SGAs, on Egr3 ${ }^{-1-}$ mice. They suppress locomotor activity in WT mice at dosages that partially or completely reverse the hyperactivity of $\mathrm{Egr}^{-1-}$ mice, but do not reduce their activity below that of vehicle-treated WT mice. However, although these agents show a similar divergence in their locomotor suppressive effects on WT and $E g r 3^{-1-}$ mice as do the SGAs, they do not suppress the locomotor activity of WT mice to the same degree as the SGAs, which block movements in a $1 \mathrm{~h}$ test to nearly zero. Thus, although the reduction in PFC $5 \mathrm{HT}_{2 \mathrm{~A}} \mathrm{Rs}$ may be sufficient to reduce sensitivity of $\mathrm{Egr}^{-1-}$ mice to the locomotor suppressive effects of SGAs, the blockade of other receptors in combination with $5 \mathrm{HT}_{2 \mathrm{~A}} \mathrm{Rs}$ may be contributing to the activity-suppressing effects of SGAs in WT mice. Finally, the possibility that the $5 \mathrm{HT}_{2 \mathrm{~A}} \mathrm{R}$ may contribute to the sedating effects of SGAs in humans is less surprising when one considers that $5 \mathrm{HT}_{2 \mathrm{~A}} \mathrm{R}$-specific antagonists and inverse agonists are being investigated by the pharmaceutical industry as sleep aids (Teegarden et al, 2008).

Our findings are consistent with those of McOmish and colleagues (2010), who recently reported that $5 \mathrm{HT}_{2 \mathrm{~A}} \mathrm{R}^{-1-}$ mice show the same resistance to the locomotor suppression produced in WT mice by clozapine that we previously reported in $E g r 3^{-1-}$ mice. Using a conditional regional rescue of $5 \mathrm{HT}_{2 \mathrm{~A}} \mathrm{R}$ function, they demonstrated that this response results from loss of $5 \mathrm{HT}_{2 \mathrm{~A}} \mathrm{Rs}$ in the cortex, and is not caused by receptor loss in the striatum. This suggests that the reduction in $5 \mathrm{HT}_{2 \mathrm{~A}} \mathrm{Rs}$ we have identified in the cortex of $\mathrm{Egr3}^{-1-}$ mice is, indeed, responsible for their differential response to clozapine and other SGAs, compared with FGAs.

Our study does not address whether the loss of $5 \mathrm{HT}_{2 \mathrm{~A}} \mathrm{R}$ expression may contribute to other phenotypes that the $\mathrm{Egr3}^{-l-}$ mice display, including schizophrenia-like behavioral abnormalities (Gallitano-Mendel et al, 2007; (Gallitano-Mendel et al, 2008). However, the nearly $70 \%$ reduction in cortical $5 \mathrm{HT}_{2 \mathrm{~A}} \mathrm{Rs}$ does not appear to disrupt the effectiveness of clozapine, as we have previously reported that chronic clozapine is able to reverse the aggressive behavior of Egr3 ${ }^{-1-}$ mice (Gallitano-Mendel et al, 2008). This is consistent with a recent report by Yadav and co-workers (2011), which demonstrated that 
post-synaptic $5 \mathrm{HT}_{2 \mathrm{~A}} \mathrm{Rs}$ are not essential for clozapine's ability to reverse phencyclidine-induced disruption of sensory-motor gating in mice, an NMDAR hypofunction animal model of schizophrenia.

\section{FGA and SGA Antipsychotics}

Inspection of the binding profiles of the FGAs and SGAs, as shown in Table 2, does not reveal a single receptor that can explain the differential susceptibility of $\mathrm{Egr3}^{-1-}$ mice to the locomotor suppressive actions of these two classes of drugs. Like SGAs, the FGAs also bind to $5 \mathrm{HT}_{2 \mathrm{~A}} \mathrm{Rs}$. In fact, the affinity of chlorpromazine for the $5 \mathrm{HT}_{2 \mathrm{~A}} \mathrm{R}$ is nearly identical to that of olanzapine and ziprasidone and, according to the PDSP source (Roth, 2008), is greater than that of clozapine. As noted earlier, the ratio of $5 \mathrm{HT}_{2 \mathrm{~A}} \mathrm{R}$ to dopamine D2 receptor affinities appears to most closely align with the differential susceptibility of $\mathrm{Egr}^{-1-}$ mice to locomotor suppressive effects of these drugs. Notably, Meltzer and co-workers (1989, 2003) have hypothesized that the 5HT2AR:D2R ratio is the main characteristic that distinguishes the FGAs from SGAs.

Despite the importance of SGAs, which became first-line treatments for schizophrenia from the late 1990s to early 2000s, there is no simple experimental assay for distinguishing FGAs from SGAs. Such an assay would be beneficial for screening novel candidate molecules for antipsychotic characteristics (Geyer and Ellenbroek, 2003). One screening test has been reported, but it involves extensive behavioral training of animals followed by multiple pharmacological interventions, and is thus difficult and time-intensive (Philibin et al, 2005). Our finding that the behavioral response of $E g r 3^{-l-}$ mice appears to distinguish SGAs from FGAs suggests that these mice may provide a rapid assay for this purpose.

Further work is needed to identify the etiology of the reduced $\mathrm{PFC} 5 \mathrm{HT}_{2 \mathrm{~A}} \mathrm{R}$ binding in $\mathrm{Egr3}^{-1-}$ mice. In particular, studies aimed at identifying whether the dysfunction is at the level of protein localization or translation, or gene expression, must be undertaken. These studies are challenging as antibodies against the $5 \mathrm{HT}_{2 \mathrm{~A}} \mathrm{R}$ have been notoriously poor for immunohistochemical and western blot methods. While there has been some recent progress in this area, they still provide poor anatomical resolution (Weber and Andrade, 2010) and are less sensitive than radiological receptor binding assays. As Egr3 is a transcription factor, it is intriguing to hypothesize that it may directly regulate expression of the Htr2a gene. However, as an immediate-early gene, Egr3 expression is stimulus-dependent and its basal expression is low. We have found that systematic induction of Egr3 expression is necessary to identify putative target genes. These studies are beyond the scope of the current report, but are important areas for future investigation to identify the mechanism by which Egr3 influences this important receptor.

\section{ACKNOWLEDGEMENTS}

We are grateful to L Muppana, MS, for animal colony maintenance and technical assistance; to $\mathrm{W}$ Rodriguez for experimental assistance; to B Appelhans, PhD, Rush
University Medical Center, for statistics consultation; to $\mathrm{H}$ Meltzer, MD, Northwestern University, for his donation of ACP-103 and his advice throughout the project; and to both $\mathrm{H}$ Meltzer, MD, and D Kupfer, MD, University of Pittsburgh, for their critical reading of the manuscript. Ki determinations, receptor binding profiles, and agonist and/or antagonist functional data, were generously provided by the National Institute of Mental Health's Psychoactive Drug Screening Program, Contract No. HHSN-271-2008-00025-C (NIMH PDSP). The NIMH PDSP is Directed by Bryan L Roth MD, PhD at the University of North Carolina at Chapel Hill and Project Officer Jamie Driscol at NIMH, Bethesda MD, USA. This work was supported by a NARSAD/Sidney R Baer Jr Foundation Young Investigator Award (to ALG), an Arizona Biomedical Research Commission grant (to ALG), and by NIH Grant R01 MH084894 (to JGM). Additional support from Science Foundation Arizona (to AAW), and from the Howard Hughes Medical Institute through the Undergraduate Science Education program and the School of Life Sciences at Arizona State University, is gratefully acknowledged.

\section{DISCLOSURE}

The authors declare no conflict of interest.

\section{REFERENCES}

Aitchison KJ, Jann MW, Zhao JH, Sakai T, Zaher H, Wolff K et al (2000). Clozapine pharmacokinetics and pharmacodynamics studied with Cyp1A2-null mice. J Psychopharmacol 14: 353-359.

Allen NC, Bagade S, McQueen MB, Ioannidis JP, Kavvoura FK, Khoury MJ et al (2008). Systematic meta-analyses and field synopsis of genetic association studies in schizophrenia: the SzGene database. Nat Genet 40: 827-834.

Alves HN, da Silva AL, Olsson IA, Orden JM, Antunes LM (2010). Anesthesia with intraperitoneal propofol, medetomidine, and fentanyl in rats. J Am Assoc Lab Anim Sci 49: 454-459.

Bespalov A, Jongen-Relo AL, van Gaalen M, Harich S, Schoemaker $\mathrm{H}$, Gross $\mathrm{G}$ (2007). Habituation deficits induced by metabotropic glutamate receptors $2 / 3$ receptor blockade in mice: reversal by antipsychotic drugs. J Pharmacol Exp Ther 320: 944-950.

Buckton G, Zibrowski EM, Vanderwolf CH (2001). Effects of cyclazocine and scopolamine on swim-to-platform performance in rats. Brain Res 922: 229-233.

Casey DE (1997). The relationship of pharmacology to side effects. $J$ Clin Psychiatry 58(Suppl 10): 55-62.

Cosi C, Waget A, Rollet K, Tesori V, Newman-Tancredi A (2005). Clozapine, ziprasidone and aripiprazole but not haloperidol protect against kainic acid-induced lesion of the striatum in mice, in vivo: role of 5-HT1A receptor activation. Brain Res 1043: 32-41.

Crawley JN (1981). Neuropharmacologic specificity of a simple animal model for the behavioral actions of benzodiazepines. Pharmacol Biochem Behav 15: 695-699.

Cutler NR (2001). Pharmacokinetic studies of antipsychotics in healthy volunteers versus patients. J Clin Psychiatry 62(Suppl 5): 10-13; discussion 23-14.

Darmani NA, Martin BR, Pandey U, Glennon RA (1990). Do functional relationships exist between 5-HT1A and 5-HT2 receptors? Pharmacol Biochem Behav 36: 901-906.

Dean B, Hayes W (1996). Decreased frontal cortical serotonin2A receptors in schizophrenia. Schizophr Res 21: 133-139. 
Dougherty JP, Aloyo VJ (2011). Pharmacological and behavioral characterization of the 5-HT2A receptor in $\mathrm{C} 57 \mathrm{BL} / 6 \mathrm{~N}$ mice. Psychopharmacology (Berl) 215: 581-593.

Erritzoe D, Rasmussen H, Kristiansen KT, Frokjaer VG, Haugbol S, Pinborg L et al (2008). Cortical and subcortical 5-HT2A receptor binding in neuroleptic-naive first-episode schizophrenic patients. Neuropsychopharmacology 33: 2435-2441.

Fox MA, Stein AR, French HT, Murphy DL (2010). Functional interactions between 5-HT2A and presynaptic 5-HT1A receptorbased responses in mice genetically deficient in the serotonin 5HT transporter (SERT). Br J Pharmacol 159: 879-887.

Fukushiro DF, Alvarez Jdo N, Tatsu JA, de Castro JP, Chinen CC, Frussa-Filho R (2007). Haloperidol (but not ziprasidone) withdrawal enhances cocaine-induced locomotor activation and conditioned place preference in mice. Prog Neuropsychopharmacol Biol Psychiatry 31: 867-872.

Gainetdinov RR, Mohn AR, Caron MG (2001). Genetic animal models: focus on schizophrenia. Trends Neurosci 24: 527-533.

Gallitano-Mendel A, Izumi Y, Tokuda K, Zorumski CF, Howell MP, Muglia LJ et al (2007). The immediate early gene early growth response gene 3 mediates adaptation to stress and novelty. Neuroscience 148: 633-643.

Gallitano-Mendel A, Wozniak DF, Pehek EA, Milbrandt J (2008). Mice lacking the immediate early gene Egr3 respond to the antiaggressive effects of clozapine yet are relatively resistant to its sedating effects. Neuropsychopharmacology 33: 1266-1275.

Garbett K, Gal-Chis R, Gaszner G, Lewis DA, Mirnics K (2008). Transcriptome alterations in the prefrontal cortex of subjects with schizophrenia who committed suicide. Neuropsychopharmacol Hung 10: 9-14.

Geyer MA, Ellenbroek B (2003). Animal behavior models of the mechanisms underlying antipsychotic atypicality. Prog Neuropsychopharmacol Biol Psychiatry 27: 1071-1079.

Gonzalez-Maeso J, Ang RL, Yuen T, Chan P, Weisstaub NV, LopezGimenez JF et al (2008). Identification of a serotonin/glutamate receptor complex implicated in psychosis. Nature 452: 93-97.

Gonzalez-Maeso J, Yuen T, Ebersole BJ, Wurmbach E, Lira A, Zhou $\mathrm{M}$ et al (2003). Transcriptome fingerprints distinguish hallucinogenic and nonhallucinogenic 5-hydroxytryptamine $2 \mathrm{~A}$ receptor agonist effects in mouse somatosensory cortex. J Neurosci 23: 8836-8843.

Guo AY, Sun J, Jia P, Zhao Z (2010). A novel microRNA and transcription factor mediated regulatory network in schizophrenia. BMC Syst Biol 4: 10.

Hippenmeyer S, Shneider NA, Birchmeier C, Burden SJ, Jessell TM, Arber S (2002). A role for neuregulin1 signaling in muscle spindle differentiation. Neuron 36: 1035-1049.

Hurlemann R, Matusch A, Kuhn KU, Berning J, Elmenhorst D, Winz O et al (2008). 5-HT2A receptor density is decreased in the at-risk mental state. Psychopharmacology (Berl) 195: 579-590.

Jacobson C, Duggan D, Fischbach G (2004). Neuregulin induces the expression of transcription factors and myosin heavy chains typical of muscle spindles in cultured human muscle. Proc Natl Acad Sci USA 101: 12218-12223.

Kamei J, Hirano S, Miyata S, Saitoh A, Onodera K (2005). Effects of first- and second-generation histamine-H1-receptor antagonists on the pentobarbital-induced loss of the righting reflex in streptozotocin-induced diabetic mice. J Pharmacol Sci 97: 266-272.

Kane J, Honigfeld G, Singer J, Meltzer H (1988). Clozapine for the treatment-resistant schizophrenic. A double-blind comparison with chlorpromazine. Arch Gen Psychiatry 45: 789-796.

Kehne JH, Baron BM, Carr AA, Chaney SF, Elands J, Feldman DJ et al (1996). Preclinical characterization of the potential of the putative atypical antipsychotic MDL 100,907 as a potent 5-HT2A antagonist with a favorable CNS safety profile. J Pharmacol Exp Ther 277: 968-981.
Khan Z, Carey J, Park HJ, Lehar M, Lasker D, Jinnah HA (2004). Abnormal motor behavior and vestibular dysfunction in the stargazer mouse mutant. Neuroscience 127: 785-796.

Kim SH, Song JY, Joo EJ, Lee KY, Ahn YM, Kim YS (2010). EGR3 as a potential susceptibility gene for schizophrenia in Korea. Am J Med Genet B 153B: 1355-1360.

Kinkead B, Dobner PR, Egnatashvili V, Murray T, Deitemeyer N, Nemeroff CB (2005). Neurotensin-deficient mice have deficits in prepulse inhibition: restoration by clozapine but not haloperidol, olanzapine, or quetiapine. J Pharmacol Exp Ther 315: 256-264.

Kyncl JJ (1986). Pharmacology of terazosin. Am J Med 80: 12-19.

Lein ES, Hawrylycz MJ, Ao N, Ayres M, Bensinger A, Bernard A et al (2007). Genome-wide atlas of gene expression in the adult mouse brain. Nature 445: 168-176.

Lopez-Figueroa AL, Norton CS, Lopez-Figueroa MO, ArmelliniDodel D, Burke S, Akil H et al (2004). Serotonin 5-HT1A, 5$\mathrm{HT} 1 \mathrm{~B}$, and 5-HT2A receptor mRNA expression in subjects with major depression, bipolar disorder, and schizophrenia. Biol Psychiatry 55: 225-233.

Lynch III JJ, Castagne V, Moser PC, Mittelstadt SW (2011). Comparison of methods for the assessment of locomotor activity in rodent safety pharmacology studies. J Pharmacol Toxicol Methods 64: 74-80.

MacDonald E, Scheinin M, Scheinin H, Virtanen R (1991). Comparison of the behavioral and neurochemical effects of the two optical enantiomers of medetomidine, a selective alpha-2adrenoceptor agonist. J Pharmacol Exp Ther 259: 848-854.

Matsumoto I, Inoue Y, Iwazaki T, Pavey G, Dean B (2005). 5-HT2A and muscarinic receptors in schizophrenia: a postmortem study. Neurosci Lett 379: 164-168.

McNamara RK, Logue A, Stanford K, Xu M, Zhang J, Richtand NM (2006). Doseresponse analysis of locomotor activity and stereotypy in dopamine D3 receptor mutant mice following acute amphetamine. Synapse 60: 399-405.

McOmish CE, Lira A, Hanks JB, Gingrich JA (2010). Clozapineinduced locomotor suppression is mediated by the cortical 5-HT2A receptor in mice. Neuropsychopharmacology 35: S228.

Meltzer HY, Huang M (2008). In vivo actions of atypical antipsychotic drug on serotonergic and dopaminergic systems. Prog Brain Res 172: 177-197.

Meltzer HY, Li Z, Kaneda Y, Ichikawa J (2003). Serotonin receptors: their key role in drugs to treat schizophrenia. Prog Neuropsychopharmacol Biol Psychiatry 27: 1159-1172.

Meltzer HY, Matsubara S, Lee JC (1989). The ratios of serotonin2 and dopamine2 affinities differentiate atypical and typical antipsychotic drugs. Psychopharmacol Bull 25: 390-392.

Meltzer HY, Mills R, Revell S, Williams H, Johnson A, Bahr D et al (2010). Pimavanserin, a serotonin(2A) receptor inverse agonist, for the treatment of parkinson's disease psychosis. Neuropsychopharmacology 35: 881-892.

Mexal S, Frank M, Berger R, Adams CE, Ross RG, Freedman R et al (2005). Differential modulation of gene expression in the NMDA postsynaptic density of schizophrenic and control smokers. Brain Res Mol Brain Res 139: 317-332.

Mittelstadt PR, Ashwell JD (1998). Cyclosporin A-sensitive transcription factor Egr-3 regulates Fas ligand expression. Mol Cell Biol 18: 3744-3751.

Moore NA, Tye NC, Axton MS, Risius FC (1992). The behavioral pharmacology of olanzapine, a novel 'atypical' antipsychotic agent. J Pharmacol Exp Ther 262: 545-551.

Ngan ET, Yatham LN, Ruth TJ, Liddle PF (2000). Decreased serotonin $2 \mathrm{~A}$ receptor densities in neuroleptic-naive patients with schizophrenia: A PET study using [(18)F]setoperone. Am J Psychiatry 157: 1016-1018.

O'Dell LE, Kreifeldt MJ, George FR, Ritz MC (2000). The role of serotonin(2) receptors in mediating cocaine-induced convulsions. Pharmacol Biochem Behav 65: 677-681. 
Oduola OO, Happi TC, Gbotosho GO, Ogundahunsi OA, Falade CO, Akinboye DO et al (2004). Plasmodium berghei: efficacy and safety of combinations of chloroquine and promethazine in chloroquine resistant infections in gravid mice. Afr J Med Med Sci 33: 77-81.

Olney JW, Newcomer JW, Farber NB (1999). NMDA receptor hypofunction model of schizophrenia. J Psychiatr Res 33: 523-533.

Owen MJ, Craddock N, O'Donovan MC (2010). Suggestion of roles for both common and rare risk variants in genome-wide studies of schizophrenia. Arch Gen Psychiatry 67: 667-673.

Parsons ME, Ganellin CR (2006). Histamine and its receptors. Br J Pharmacol 147(Suppl 1): S127-S135.

Philibin SD, Prus AJ, Pehrson AL, Porter JH (2005). Serotonin receptor mechanisms mediate the discriminative stimulus properties of the atypical antipsychotic clozapine in C57BL/6 mice. Psychopharmacology (Berl) 180: 49-56.

Pierre JM (2005). Extrapyramidal symptoms with atypical antipsychotics: incidence, prevention and management. Drug Saf 28: 191-208.

Rasmussen H, Erritzoe D, Andersen R, Ebdrup BH, Aggernaes B, Oranje B et al (2010). Decreased frontal serotonin2A receptor binding in antipsychotic-naive patients with first-episode schizophrenia. Arch Gen Psychiatry 67: 9-16.

Rasmussen T, Fink-Jensen A (2000). Intravenous scopolamine is potently self-administered in drug-naive mice. Neuropsychopharmacology 22: 97-99.

Redrobe JP, Bourin M (1997). Partial role of 5-HT2 and 5-HT3 receptors in the activity of antidepressants in the mouse forced swimming test. Eur J Pharmacol 325: 129-135.

Rosen GD, Capra JA, Connolly MT, Cruz B, Lu L, Airey DC et al. (2000). The Mouse Brain Library. Int Mouse Genome Conf 14: 166.

Roth BL. Psychoactive Drug Screening Program, Contract No. HHSN-271-2008-00025-C (NIMH PDSP) 2008. http://pdsp.med. unc.edu/.

Roth BL, Sheffler DJ, Kroeze WK (2004). Magic shotguns versus magic bullets: selectively non-selective drugs for mood disorders and schizophrenia. Nat Rev Drug Discov 3: 353-359.

Serretti A, Drago A, De Ronchi D (2007). HTR2A gene variants and psychiatric disorders: a review of current literature and selection of SNPs for future studies. Curr Med Chem 14: 2053-2069.

Shishido S, Oishi R, Saeki K (1991). In vivo effects of some histamine H1-receptor antagonists on monoamine metabolism in the mouse brain. Naunyn Schmiedebergs Arch Pharmacol 343: $185-189$.

Simon VM, Parra A, Minarro J, Arenas MC, Vinader-Caerols C, Aguilar MA (2000). Predicting how equipotent doses of chlorpromazine, haloperidol, sulpiride, raclopride and clozapine reduce locomotor activity in mice. Eur Neuropsychopharmacol 10: $159-164$.

Stahl S (2008). Stahl's Essential Psychopharmacology; 3rd edn. Cambridge University Press: New York, 1117pp.

Stefansson H, Sigurdsson E, Steinthorsdottir V, Bjornsdottir S, Sigmundsson T, Ghosh $S$ et al (2002). Neuregulin 1 and susceptibility to schizophrenia. Am J Hum Genet 71: 877-892.
Teegarden BR, Al Shamma H, Xiong Y (2008). 5-HT(2A) inverseagonists for the treatment of insomnia. Curr Top Med Chem 8: 969-976.

Tourtellotte WG, Milbrandt J (1998). Sensory ataxia and muscle spindle agenesis in mice lacking the transcription factor Egr3. Nat Genet 20: 87-91.

Vanderwolf CH (1991). Anti-muscarinic drug effects in a swim-toplatform test: dose-response relations. Behav Brain Res 44: 217-219.

Vanover KE, Weiner DM, Makhay M, Veinbergs I, Gardell LR, Lameh J et al (2006). Pharmacological and behavioral profile of $N$-(4-fluorophenylmethyl)- $N$-(1-methylpiperidin-4-yl)- $N^{\prime}$-(4-(2methylpropylo $x y$ )phenylmethyl) carbamide $(2 R, 3 R)$-dihydroxybutanedioate (2:1) (ACP-103), a novel 5-hydroxytryptamine(2A) receptor inverse agonist. J Pharmacol Exp Ther 317: 910-918.

Votava M, Hess L, Krsiak M (2008). Selective antiaggressive effect of an alpha-2 adrenoceptor agonist naphthylmedetomidine in mice. Aggress Behav 34: 394-403.

Weber ET, Andrade R (2010). Htr2a gene and 5-HT(2A) receptor expression in the cerebral cortex studied using genetically modified mice. Front Neurosci 4.

Wishart DS, Knox C, Guo AC, Cheng D, Shrivastava S, Tzur D et al (2008). DrugBank: a knowledgebase for drugs, drug actions and drug targets. Nucleic Acids Res 36: D901-D906.

Wishart DS, Knox C, Guo AC, Shrivastava S, Hassanali M, Stothard $\mathrm{P}$ et al (2006). DrugBank: a comprehensive resource for in silico drug discovery and exploration. Nucleic Acids Res 34: D668-D672.

Yadav PN, Abbas AI, Farrell MS, Setola V, Sciaky N, Huang XP et al (2011). The presynaptic component of the serotonergic system is required for clozapine's efficacy. Neuropsychopharmacology 36: 638-651.

Yamada K, Gerber DJ, Iwayama Y, Ohnishi T, Ohba H, Toyota T et al (2007). Genetic analysis of the calcineurin pathway identifies members of the EGR gene family, specifically EGR3, as potential susceptibility candidates in schizophrenia. Proc Natl Acad Sci USA 104: 2815-2820.

Yamagata K, Kaufmann WE, Lanahan A, Papapavlou M, Barnes CA, Andreasson KI et al (1994). Egr3/Pilot, a zinc finger transcription factor, is rapidly regulated by activity in brain neurons and colocalizes with Egr1/zif268. Learn Mem 1: 140-152.

Yan B, He J, Xu H, Zhang Y, Bi X, Thakur S et al (2007). Quetiapine attenuates the depressive and anxiolytic-like behavioural changes induced by global cerebral ischemia in mice. Behav Brain Res 182: 36-41.

Zarnowski T, Kleinrok Z, Turski WA, Czuczwar SJ (1994). The NMDA antagonist procyclidine, but not ifenprodil, enhances the protective efficacy of common antiepileptics against maximal electroshockinduced seizures in mice. J Neural Transm Gen Sect 97: 1-12.

Zhang R, Lu S, Meng L, Min Z, Tian J, Valenzuela RK (2012). Genetic evidence for the association between the early growth response 3 (EGR3) gene and schizophrenia. PLoS One 7: e30237.

Zhu CZ, Wilson SG, Mikusa JP, Wismer CT, Gauvin DM, Lynch III JJ et al (2004). Assessing the role of metabotropic glutamate receptor 5 in multiple nociceptive modalities. Eur J Pharmacol 506: $107-118$.

Supplementary Information accompanies the paper on the Neuropsychopharmacology website (http://www.nature.com/npp) 